\title{
The vanishing law of Crown act of state Paul SCOTT
}

Lecturer in Public Law, University of Southampton*

\begin{abstract}
Introduction
$\mathrm{T}$ The doctrine of Crown act of state, ${ }^{1}$ which permits the Crown to resist claims in tort brought against it on the basis that the action giving rise to the allegedly tortious act constituted an 'act of state', has never enjoyed any great clarity. ${ }^{2}$ No wonder: it has been for much of its history little more than an extrapolation from a small number of disparate and unusual cases, some of them barely reasoned and most of which belong to a very different constitutional era. ${ }^{3}$ The recent judgment of the Court of Appeal in the joined appeals in Serdar Mohammed $v$ Ministry of Defence and Rabmatullab v Ministry of Defence, ${ }^{4}$ together with the first instance decisions of Leggatt $J$ in each case, ${ }^{5}$ amounts to a much-needed clarification and modernisation of a doctrine which stands as one of the constitution's more uncertain and anachronistic elements. This article maps the effect of these recent decisions on the substance of the doctrine, arguing that not only have they deprived the doctrine of much of its assumed effect but that they in fact demonstrate that the doctrine is really no such
\end{abstract}

* I thank Mark Telford and Marta Iljadica for their comments on earlier versions of the present work. My thoughts on this question were heavily influenced by a number of long conversations with Matt Nicholson on this and related issues and I thank him for his time and insight.

1 Alternatively, 'British' or 'domestic' act of state. The doctrine in question is labelled as such so as to distinguish it from the separate doctrine now known as 'foreign act of state'. On the relation between the two, see most recently Serdar Mohammed v Secretary of State for Defence [2015] EWCA Civ 843, [375]: 'The two principles [foreign act of state and crown act of state] are distinct and, in our view, have different rationales.' On foreign act of state, see the recent case of Belhaj v Straw [2014] EWCA Civ 1394 and, discussing it in the context of the doctrine's development, Matthew Nicholson, 'The Political Unconscious of the English Foreign Act of State and Non-Justiciability Doctrine(s)' (2015) 64 International and Comparative Law Quarterly 743. One of the cases discussed in the present work - Rahmatullah v Ministry of Defence [2014] EWHC 3846 (QB) - also raised issues of foreign act of state. Those issues were separated out and joined with Belhaj on appeal to the Supreme Court, with argument taking place in November 2015.

2 Perhaps the most impressive attempt to make sense of the issue is Amanda Perreau-Saussine, 'British Acts of State in English Courts' (2008) 78 British Yearbook of International Law 176.

3 Amongst them the following: Buron v Denman (1848) 2 Exch 167, 154 ER 450; Walker v Baird [1892] AC 491; Poll v Lord Advocate (1899) 1 F 823, (1897) 5 SLT 167; Johnstone v Pedlar [1921] 2 AC 262; Nissan v Attorney General [1970] AC 179.

4 [2015] EWCA Civ 843.

5 Serdar Mohammed v Ministry of Defence [2014] EWHC 1369 (QB); Yunus Rabmatullab v Ministry of Defence [2014] EWHC 3846 (QB). 
thing. It has crumbled under scrutiny and talk of it, which obscures rather than illuminates the key questions about the role of the courts in relation to the Crown's torts abroad, should now be abandoned.

\section{Some background}

Crown Act of state reflects certain background features of the historical and contemporary constitutional order. The first is the exclusion of the Crown's prerogative powers from the jurisdiction of the courts, which in the past would review the existence and scope of the power in question - and so establish whether what had been done by

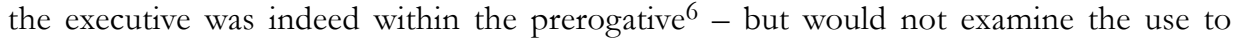
which such powers were put. ${ }^{7}$ The second is the rule - one of the 'legal prerogatives' of the Crown - that 'the King can do no wrong', glossed by Chitty as meaning that 'his Majesty, individually and personally, and in his natural capacity . . . is not amenable to any other earthly power or jurisdiction . . . The law supposes it impossible that the King himself can act unlawfully or improperly.'8 The effect of this, said Chitty, was that, at least since the reign of Edward I, 'the Crown has been free from any action at the suit of its subjects'. 9 The common law recognised instead in the context of certain claims (including those relating to individual property rights) a mode of proceeding against the Crown known as a 'petition of right' which was codified and regularised by a statute of $1860 .{ }^{10}$ A petition of right was severely limited in its scope. First, permission to bring a petition was required, though in practice not refused where a prima facie case was established. Moreover, it was 'a fatal bar to the success of a petition of right to allege a tortious act on the part of the Crown ... for such an allegation violated the rule that the Crown could do no wrong, and that rule has not been abrogated either at common law or by the Petitions of Right Act, 1860 '.11 Where a petition of right was unavailable, an alternative would be to bring a personal action against any Crown servant who could be identified as responsible for the wrongful act, reflecting the claim that: 'although in the eyes of his courts the king can do no wrong, a wrong apparently done by the king could be attributed to his servants, and that those servants, however, senior, were answerable not solely to the king but also to the courts'. ${ }^{12}$ The opportunity to bring an action against the Crown's servants or agents in person - though the basis of some of the common law's most celebrated decisions protecting individual liberty ${ }^{13}$ - was subject to the possibility that the Crown would ratify or adopt the action of its servants (if it had not authorised it in

6 See e.g. Coke in The Case of Proclamations (1611) 12 Co Rep 74, 77 ER 1352: 'the King hath no prerogative but that which the law of the land allows him'.

7 See e.g. China Navigation Company v Attorney General [1932] 2 KB 197.

8 Joseph Chitty, A Treatise on the Law of the Prerogatives of the Crown: And the Relative Duties and Rights of the Subject (J Butterworth \& Son 1820) 5.

9 Ibid 339.

10 Petitions of Right Act 1860.

11 E C S Wade, 'Liability in Tort of the Central Government of the United Kingdom' (1954) 29 New York University Law Review 1416, 1418. The case usually taken as establishing that rule is Viscount Canterbury $v$ Attorney General (1842) $1 \mathrm{Ph}$ 306, though Perreau-Saussine (n 2) 230 says that the justification offered by the judge in the case, Lord Lyndhurst LC, for the relevant conclusion is 'dubious because so confused'. See also Tobin $v$ R (1864) 16 CBNS 310 and Feather $v$ R (1865) 6 B \& S 257.

12 Perreau-Saussine (n 2) 229.

13 Most obviously, Entick $v$ Carrington (1765) 19 State Trials 1029. This possibility was often exploited by the Crown in order to undercut its own immunity: it would nominate a servant against whom an action in tort might be brought and indemnify that person for damages and costs. For the deprecation and then rejection of this practice by the courts, see Adams v Naylor [1946] AC 543 and Royston v Cavey [1947] KB 204. 
advance), leaving only the (empty) possibility of an action against the Crown itself or some extrajudicial remedy. ${ }^{14}$ Both the non-reviewability of the prerogative generally and the specific immunity of the Crown in its own courts must be borne in mind when considering the nature and historical operation and development of the doctrine of Crown act of state. Both, however, have been significantly eroded - the former, as we shall see, by a series of decisions of the English courts over the last 30 or so years; the latter by the enactment of the Crown Proceedings Act $1947 .{ }^{15}$ These developments call into question the traditional understanding of Crown act of state.

A third contextual factor is choice of laws. Previously, a tort committed abroad could be the basis of a claim in the English courts only if the conduct giving rise to it was recognised as a tort by both English law and the law of the jurisdiction in which it occurred - this was the 'double actionability' rule. ${ }^{16}$ Since the enactment of the Private Law (Miscellaneous Provisions) Act 1995, however, the general rule is that, for the purposes of tort, 'the applicable law is the law of the country in which the events constituting the tort or delict in question occur'. ${ }^{17}$ Given that the doctrine of Crown act of state does not apply to actions carried out in Britain (with the possible but now perhaps unlikely exception of those perpetrated upon hostile aliens), ${ }^{18}$ the effect will normally be that the law governing situations in which the doctrine is invoked will be foreign law, the content of which must be proved as a question of fact. The applicability of foreign law to the relevant facts does not, though, preclude the pleading of Crown act of state: the doctrine is a rule of procedure and so 'its availability is governed by English law as the law of the forum'. ${ }^{19}$ This presumes that England is in fact the forum in which the relevant claims are brought. It usually will be, not least because the relevant claims are being brought against a minister of the Crown. A successful plea of Crown act of state, in either of the two forms which the doctrine takes, will not prevent the claim thereby repelled from being brought in another jurisdiction: it is likely, however, that such a course of action is, for any number of reasons, substantially less attractive than is proceeding in an English court.

\section{The dualism of Crown act of state}

Though, considered holistically, the doctrine of Crown act of state is much diminished by them, a key feature of the most recent round of judgments is the reaffirmation, in the face of direct challenge, of the doctrine's dualism: the existence within it of two separate rules, one which identifies certain matters as non-justiciable and so prevents their consideration by English courts altogether, and another which provides a defence to a claim in tort arising out of conduct which the courts would otherwise be willing and able

14 Buron v Denman (1848) 2 Exch 167.

15 Crown Proceedings Act 1947, s 2. On that Act, see generally Glanville Williams, Crown Proceedings (Stevens \& Sons 1948). For an account of the debates leading to its enactment, see Joseph M Jacob, 'The Debates behind an Act: Crown Proceedings Reform 1920-1947’ [1992] Public Law 452.

16 On which see Phillips v Eyre (1870) LR 6 QB 1 and Boys $v$ Chaplin [1971] AC 356. The rule was abolished by s 10 of the Private Law (Miscellaneous Provisions) Act 1995.

17 Private Law (Miscellaneous Provisions) Act 1995, s 11(1). An exception exists where it is 'substantially more appropriate' for the applicable law to be that of another country, in which case the law of that country is preferred': Private Law (Miscellaneous Provisions) Act 1995, s 12.

18 Johnstone v Pedlar [1921] 2 AC 262.

19 Yunus Rahmatullah v Ministry of Defence [2014] EWHC 3846 (QB), [218] (fn). See: Private Law (Miscellaneous Provisions) Act 1995, s 14(3)(b): '[N]othing in this part . . . affects any rules of evidence, pleading or practice or authorises questions of procedure in any proceedings to be determined otherwise than in accordance with the law of the forum.' 
to consider. The origin of that dualism is Buron $v$ Denman. ${ }^{20}$ The defendant (a naval commander) was tasked by the governor of Sierra Leone with freeing two British captives detained as slaves on the Gallinas islands, at the mouth of the eponymous river. ${ }^{21}$ In doing so Denman took possession of and then destroyed barraccoons (slave huts) belonging to Buron, a Spanish slave trader, and took Buron's slaves back to Sierra Leone to be liberated. All this was the subject of vast praise from ministers and naval figures. When Buron sued in trespass, the central question was whether Denman's conduct could be 'justified as an act of state, done by authority of the Crown'. 22 That is, was the subsequent ratification of the act, in terms of approving letters sent by various secretaries of state and the Lord of the Admiralty upon becoming aware of it, equivalent to prior authority? Though the judge whose summing-up is reported, Parke B, was less sure on this point than his brethren, the majority in the Exchequer Court held in the affirmative, leaving Buron with a remedy only against the Crown via a petition of right ${ }^{23}$ or, in the alternative, the possibility of seeking some diplomatic remedy.

The context of the decision in Buron was such that no enquiry into the concept of act of state, or its significance, was undertaken: what mattered was that Denman's potential individual liability was extinguished by the subsequent ratification. It appears that the sole act of state case cited in argument was Elphinstone $v$ Bedreechund ${ }^{24}$ in which it had been held that a municipal court had no jurisdiction over the seizure of property carried out, in contravention of the articles of capitulation, against the governor of a conquered fortress: the character of the seizure was 'that of hostile seizure . . . regard being had both to the time, the place, and the person, and consequently that the Municipal Court had no jurisdiction to adjudge upon the subject'. ${ }^{25}$ A series of nineteenth-century cases before and after Buron concurred: certain questions were not suitable for consideration in the domestic courts. ${ }^{26}$ But, insofar as can be inferred from the brief discussion of the point, it seems that the doctrine of act of state does not operate in Buron as it did in Elphinstone. ${ }^{27}$ Instead, act of state appears to function as a defence to a claim in tort over which the courts enjoy rather than abjure jurisdiction: hence Park B's reference to Denman's actions being 'justified as an act of state'. ${ }^{28}$ And, certainly, that is how Buron has come to be treated, notwithstanding the thinness of the textual basis of that conclusion. To the older act of state rule of non-justiciability it was taken to have added a second rule: the doctrine had assumed a dualist nature.

20 Buron v Denman (1848) 2 Exch 167, 154 ER 450.

21 For a much fuller account of the background to the case, see Charles Mitchell and Leslie Turano, 'Buron $v$ Denman (1848)' in Charles Mitchell and Paul Mitchell (eds), Landmark. Cases in the Law of Tort (Hart 2010).

22 (1848) 2 Exch 167, 188.

23 Though Perreau-Saussine has neatly demonstrated the uncertainties in the application of the procedure to Buron's case (n 2) 229-32.

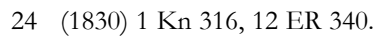

25 Ibid 360-61.

26 See e.g. Cook v Sprigg [1899] AC 572, 578: 'It is a well-established principle of law that the transactions of independent States between each other are governed by other laws than those which municipal courts administer.'

27 Though see Feather $v$ R (1865) 6 B \& S 257, 296, where Cockburn CJ takes Buron to show that 'where an act injurious to a foreigner, and which might otherwise afford a ground of action, is done by a British subject, and the act is adopted by the government of this country, it becomes the act of the state, and the private right of action becomes merged in the international question which arises between our own government and that of the foreigner'.

28 (1848) 2 Exch 167, 187 (emphasis added). 
This dualism was observed by Emelyn Wade. ${ }^{29}$ In a seminal contribution, he noted that the phrase 'act of state' was most closely associated with the defence available to Crown servants for criminal ${ }^{30}$ or tortious actions in certain circumstances (not, famously, against British subjects for acts done in Britain) ${ }^{31}$ - a rule evidenced by Buron v Denman and various cases decided since. However, "the narrow application of the term as a defence to what would otherwise be a tortious or criminal act does not explain its full scope': 32 it denoted also a category of acts not justiciable in domestic ('municipal') courts. Thus, notwithstanding that the Buron rule arose subsequently to the justiciability rule, it had by the 1930s managed to achieve priority over it. Reasoning inductively from cases of both types, Wade defined an act of state as 'an act of the Executive as a matter of policy performed in the course of its relations with another state, including its relations with the subjects of that state, unless they are temporarily within the allegiance of the Crown. 33 When Wade's distinction was taken up and filled out by Lord Mcnair, the defence again took priority, ${ }^{34}$ being stated to exist alongside 'a rule which is wider and more fundamental, namely, that "those acts of the Crown which are done under the prerogative in the sphere of foreign affairs" . . cannot form the basis of an action brought against the Crown, or its agents or servants, by any person, British or alien, or by any foreign state, in British municipal tribunals.' ${ }^{35}$ Note that the phrasing limits the non-justiciability rule in two ways: it applies to the situations involving (a) the exercise of the prerogative and even then only (b) in the realm of foreign affairs. Where Wade had identified all of the standard act of state cases as exemplifying the tort defence, however, Mcnair placed in that category only Buron $v$ Denman and Johnstone $v$ Pedlar (in which the doctrine did not apply because the claimant was a friendly alien). Walker $v$ Baird he conceptualised as an instantiation of the non-justiciability rule. Though Mcnair admitted that the scope of both limbs was obscure, as was the relation between them, he took as evidence of their distinctiveness the fact that the tort defence, unlike the non-justiciability rule, 'is not valid against a British subject'. ${ }^{36}$ 'The doctrine's dualism was accepted by the House of Lords in Nissan v Attorney General, ${ }^{37}$ but only in obiter: the doctrine was of no application there because the act in question - the taking of the plaintiff's hotel as headquarters for the British command in Cyprus - was not itself an act of state. ${ }^{38}$ Not only, therefore, is Buron a weak authority for the existence of the tort defence: it was for a long time the only such authority. The doctrine's dualism has always rested upon fragile foundations.

29 E C S Wade, 'Act of State in English Law: Its Relations with International Law' (1934) 15 British Yearbook of International Law 98. An older discussion of the doctrine is found in William Harrison Moore, Act of State in English Law (John Murray 1906).

30 On the application of the act of state doctrine to criminal acts, see James Fitzjames Stephen, $A$ History of the Criminal Law of England vol II (Macmillan \& Co 1883) 63-64. Given the reconceptualisation of the tort defence rule which has taken place in recent years (discussed below), its ability to provide a defence to criminal acts must be strongly doubted.

31 A proposition for which Wade cites Entick v Carrington (1765) 19 St Tr 1029.

32 Wade (n 29) 99.

33 Ibid 103.

34 Lord Mcnair, International Law Opinions vol I (CUP 1956) 111.

35 Ibid 112. The quoted phrase is from E C S Wade and G Godfrey Phillips, Constitutional Law 4th edn (Longman, Green \& Co 1950) 193.

36 Mcnair (n 34) 116, fn 1.

37 Nissan v Attorney-General [1970] AC 179, 220B-C (Lord Morris) and 231D (Lord Wilberforce).

38 [1970] AC 179, 215G (Lord Morris), 227B (Lord Pearce), 235H (Lord Wilberforce) and 240C-D (Lord Pearson). 
Before the Court of Appeal in the joined appeals, the dualism of Crown act of state was directly challenged, as it had been also in the High Court in Rabmatullah. The situation of Mr Rahmattullah, originally captured by British forces in Iraq and handed over to American forces who detained him in Afghanistan, has been the subject of significant attention by the English courts. ${ }^{39} \mathrm{He}$ was released from detention in Afghanistan and returned to Pakistan, his homeland, in June 2014. Crown act of state becomes relevant in the context of private law and Human Rights Act 1998 (HRA) claims brought by him against the Ministry of Defence and the Foreign Office. For reasons that will be explained shortly, Rahmatullah sought to argue that there are not - as had been said by Wade and Mcnair and accepted in Nissan v Attorney General - two limbs to the Crown act of state doctrine but only one; that 'the Crown act of state doctrine is solely a rule of justiciability and there is no separate rule which can provide a defence to a claim in tort'. ${ }^{40}$ This involved reconceptualising Buron v Denman, the case taken to evidence the existence of the tort defence, as 'merely an expression of the non-justiciability rule in a case where the defendant was an agent of the Crown, rather than the Crown itself'. ${ }^{41}$ It was argued that the significance of the post hoc ratification of Denman's acts was that those acts were thereby rendered sovereign acts 'operating at the international level of the state's relations with a foreign state and its subjects and hence as inherently non-justiciable'. ${ }^{42}$ If that was the case, then the alleged tort defence was simply a misunderstood instantiation of the non-justiciability rule rather than something separate from it. If the non-justiciability rule did not apply, then nor could - on this reading - the tort defence.

This monist reading of the doctrine is attractive: its acceptance would bring clarity and coherence to a particularly unclear area of law and, more importantly, involve abandoning the claim, to which the reading of Buron which has prevailed throughout the twentieth century amounts, that the Crown's say-so is sufficient to give rise to a defence in law to wrongful conduct upon which the courts are otherwise capable of adjudicating. What would seem to be the countervailing cost of the manoeuvre - the exclusion from the courts' jurisdiction altogether of the matters giving rise to the alleged tort - is not as great as it initially seems, given the inroads, discussed below, which both the High Court and the Court of Appeal accept as having been made into the non-justiciability rule. Crucially, this submission as to the doctrine's monism reflects both the general context and the specific terms of the decision in Buron better than does most of the literature (which accepts the existence of a separate tort defence), not asking that case to bear a burden which the very thin treatment of the matter therein cannot sustain. Given that the defence in tort which Buron is often taken as evidencing had never since been successfully pleaded in the English courts, to declare untenable the dominant reading of the case, and the doctrinal dualism to which it gives rise, would not have involved contradicting an established body of law.

Nevertheless, the monist reading of the Crown act of state doctrine was rejected both in the High Court and again in the Court of Appeal. Both courts emphasised that the existence of the act of state tort defence and thus the dualism of the Crown act of state

39 For the story of Rahmatullah's habeus corpus writ, see Rahmatullah $v$ Secretary of State for Foreign and Commonwealth Affairs [2011] EWCA Civ 1540; Rahmatullah v Secretary of State for Foreign and Commonwealth Affairs (No. 2) [2012] EWCA Civ 182; and Rahmatullah v Secretary of State for Foreign and Commonwealth Affairs (No. 2) [2012] UKSC 48.

40 Rahmatullah v Ministry of Defence [2014] EWHC 3846 (QB), [201].

41 [2014] EWHC 3846 (QB), [202].

42 Ibid [204]. For the equivalent submission in the Court of Appeal, see [2015] EWCA Civ 843, [332]-[335]. 
doctrine had been widely accepted, in Nissan and elsewhere. ${ }^{43}$ This is unfortunate - in Nissan, the act of state rule at issue was the non-justiciability rule, rather than the tort defence, and that submission failed. But on the wider point, the judges are correct: the literature clearly shows that, in the time since it was decided, Buron has had thrust upon it, consistently if not unanimously, a meaning which it does not easily bear but which the courts - or at least the lower courts - are rightly hesitant to overturn altogether. ${ }^{44}$ In rejecting the rewriting of Buron offered here, Leggatt $J$ further observed that act of state as a defence to a tort claim is 'sound in principle and rests on a proper appreciation of the separation of powers'. ${ }^{45}$ That claim played no role in the reasoning of the Court of Appeal, which instead emphasised - without explanation or elaboration - that the doctrine must have two elements because the two rules 'are applicable in different circumstances', a reference (presumably) to the fact that the non-justiciability rule, unlike the tort defence, applies also to public law claims: ${ }^{46}$ the distinction which Mcnair identified - that the non-justiciability rule alone applies to British citizens - seems now improbable. ${ }^{47}$ The logic of this point is dubious: the two rules can have differential applicability only if they first exist, and so their differential applicability is not a factor which can be adduced in favour of their existence. Nevertheless, in light of the way in which the Court of Appeal's judgment (re)frames - and, in effect, significantly narrows the act of state tort defence, principle does not count against the rule's continued existence as strongly as might otherwise have been the case. For now, it suffices to note that the opportunity of bringing coherence to the doctrine by holding it to consist of a single rule has twice been rejected, in large part upon the basis of the untested assumptions of a series of textbook writers. The Supreme Court, when it considers these issues, would be advised to offer a fuller elaboration of the point, whether or not it endorses the Court of Appeal's narrowing of the tort defence. In the meantime, the doctrine of Crown act of state retains its superficial dualism even as its two limbs are progressively eroded and its coherence as a doctrine is undermined.

\section{The non-justiciability rule}

The non-justiciability limb of Crown act of state had, before the doctrine's dualism was reaffirmed in Rabmatullah, been significantly undercut by the decision of the High Court in Serdar Mohammed - the case with which it was later joined on appeal. The claimant had been captured by British forces in Afghanistan and later transferred into the custody of the Afghan authorities. He claimed that his detention by the British forces was unlawful under both Afghan law and the HRA. Leggatt J accepted that the detention was unlawful from the point of view of both Afghan and international law. In determining the application of the non-justiciability rule, he first considered the rule's rationale, adopting

43 [2014] EWHC 3846 (QB), [208]

44 See also Nissan [1970] AC 179, 220: 'Though the conception of an act of state as illustrated in Buron v Denman has been so recognised that it cannot now be overthrown I would hope that occasions for dependence on it as a defence will become increasingly rare.'

45 [2014] EWHC 3846 (QB), [208]

46 Leggatt J In Serdar Mohammed suggests that, although Crown act of state does not 'operate in the field of public law to bar a claim for judicial review', its non-justiciability limb is 'similar if not identical to the rule that acts of the Crown which are done under the prerogative in the sphere of foreign affairs are unreviewable' [2014] EWHC 1369 (QB), [379]. For the reasons given below, this seems to be false: the non-justiciability limb of Crown act of state in effect does apply to public law claims, being simply an instantiation of the same general rule of justiciability as governs (some) uses of that prerogative. As the Court of Appeal notes: 'whether issues are justiciable cannot depend on the nature of the proceedings' [2015] EWCA Civ 843, [324].

47 [2014] EWHC 1369 (QB), [397]. 
both Elias LJ's claim in Al-Jedda (No 2) that this is a question about the relationship between executive government and the courts ("To what extent and in what circumstances should the court refuse to hold the executive to account in its dealings with foreign states or its handling of foreign relations?') 48 and the idea that the 'conceptual normative basis' of the doctrine lies in the notion of the separation of powers. ${ }^{49}$ The general principle is that 'the conduct of foreign affairs is the province of the executive arm of the state and that the judiciary should not involve itself in (or bring into jeopardy) the conduct of such affairs'. ${ }^{50}$ Note here that, unlike in Mcnair's discussion quoted earlier, the concern is purely with the subject matter of the power (foreign affairs) rather than its source.

The articulation of that principle indicates clearly the impossibility of the nonjusticiability rule working as it did in the (mostly nineteenth-century) cases which evidence it. Though it would once have been accurate to suggest that English law excluded altogether judicial oversight of the executive's exercise of the foreign affairs prerogative (as it did the prerogative as a whole), such a general proposition is no longer sustainable in light of a series of decisions which have brought the prerogative, in both its primary and secondary forms, within the jurisdiction of the courts - decisions which, crucially, post-date the last consideration of the doctrine of Crown act of state by the highest court. ${ }^{51}$ Most prominent amongst these is the GCHQ case, which confirmed a judicial willingness, flashes of which had already been visible, ${ }^{52}$ to review not merely the existence of prerogative powers but their exercise; ${ }^{53}$ from there on, prerogative powers would be excluded from review not on the basis of their source (which no longer enjoyed blanket exclusion) but on the basis of their subject matter. ${ }^{54}$ Though not listed by Lord Roskill in $G C H Q$ as one of the powers the exercise of which would by virtue of its subject matter remain beyond the courts' reach, 55 the foreign affairs prerogative was identified as such by Lord Fraser. ${ }^{56}$ The decision of the House of Lords in Bancoult (No 2), ${ }^{57}$ however, demonstrates, suggests Leggatt J, ${ }^{58}$ that, as has happened in relation to other prerogative powers singled out in $\mathrm{GCHQ}_{2},{ }^{59}$ the excluded status of the foreign affairs prerogative has itself been partially eroded. Rather than it being recognised in law that "certain areas of decision-making by the executive such as foreign policy are "no go" areas for the courts', ${ }^{60}$ the golden rule which now applies to the prerogative is that reviewability is a function of the extent to which a particular decision of the executive is 'justiciable'.

The relevance of these background shifts is that the broader Crown act of state rule - in which it operates as a rule of non-justiciability which is 'similar if not identical to the

48 Al-jedda v Secretary of State for Defence [2010] EWCA Civ 758, [197].

49 Serdar Mobammed v Ministry of Defence [2014] EWHC 1369 (QB), [373].

50 Ibid [374].

51 Which took place in Nissan v Attorney General [1970] AC 179.

$52 \mathrm{R} v$ Criminal Injuries Compensation Board ex parte Lain [1967] 2 QB 864.

53 Council of Civil Service Unions v Minister for the Civil Service [1985] AC 374.

54 Ibid 407 per Lord Scarman.

55 Ibid 418 naming 'the making of treaties, the defence of the realm, the prerogative of mercy the grant of honours, the dissolution of Parliament and the appointment of ministers'.

56 Ibid 398.

$57 \quad \mathrm{R} v$ Secretary of State for Foreign and Commonwealth Affairs ex parte Bancoult [2008] UKHL 61.

58 [2014] EWHC 1369 (QB), [376].

59 See e.g. R $v$ Ministry of Defence ex parte Smith [1996] QB 517, indicating that the management of the armed forces includes a large reviewable element.

60 [2014] EWHC 1369 (QB), [376]. 
rule that acts of the Crown which are done under the prerogative in the sphere of foreign affairs are unreviewable 61 - has been diminished. Therefore, as the non-reviewability of the prerogative in general, and that relating to foreign affairs in particular, has been chipped away at, so too has the possibility of a successful invocation of the nonjusticiability element of Crown act of state. Two points can be made about Leggatt J's treatment of the issue: first of all, though commendable from the point of view of principle, it is in large part the result of changing attitudes as to the appropriate relationship of courts and executive which are too well embedded to have been challenged here, rather than any initiative of the judge's own. Second, the question of how the tortious conduct is framed - whether it can be conceptualised as a particular decision which is itself justiciable in an English court, rather than as an aspect of a decision which directly reflects high policy - becomes vital to the question of whether the non-justiciability element of Crown act of state can be successfully pleaded. Here, it is accepted that the decision which challenged it was not one of high policy; it is not something which is 'not cognisable by the court', as Lord Pearson put it in Nissan. ${ }^{62}$ Instead, the relevant decision was that to detain a particular individual and, Leggatt J notes, rather than being the sort of decision for which the courts are ill-equipped, the legality of detention is 'quintessentially a matter for the court'. ${ }^{63}$ As such, he concluded on this point, insofar as the Crown act of state doctrine rests on a principle of justiciability, the doctrine has no application in the present case'. ${ }^{64}$ Having been in this way brought up to date in Serdar Mohammed, the non-justiciability element of the doctrine was at first instance held to be similarly incapable of repelling the claims brought by Rahmatullah. ${ }^{65}$

Much of the admirable clarity of Leggatt J's judgment on this point is missing from the Court of Appeal's reasoning in arriving at the same conclusion as did he. That court says nothing of the prerogative and instead incorporates an inconclusive discussion of the Supreme Court's consideration of non-justiciability in Shergill $v$ Khaira $-\mathrm{a}$ consideration which implicitly distinguishes the act of state doctrine from nonjusticiability proper but which seems to identify that doctrine with the tort defence limb 66 - and elements of the decision of the Court of Appeal in Al-Jedda (No 2), discussed further below. The overall effect of these considerations seems to be to leave the nonjusticiability rule where it had been left by Leggatt J, in that it prevents the consideration by the courts of 'high level policy' decisions, in relation to which there may be no judicial standards available for application by the courts, or where it would be constitutionally inappropriate for the courts to enquire into the matter: ${ }^{67}$ the manner in which these considerations interact is, however, not explored. More significant is the apparent shift in the basis of the non-justiciability rule from the rules as to the reviewability of the prerogative on the one hand to that of the general issue of justiciability on the other. This shift leaves ambiguous the question of what sort of non-justiciability is at issue in Crown

61 [2014] EWHC 1369 (QB), [379].

62 Nissan v Attorney-General [1970] AC 179, 327.

63 [2014] EWHC 1369 (QB), [381].

64 Ibid [383].

65 [2014] EWHC 3846 (QB), [200].

66 The Supreme Court refers to the doctrine 'confer[ing] immunity from liability on certain persons in respect of certain acts' [2014] UKSC 33, [41]. Moreover, the Court of Appeal in Serdar Mobammed/Rabmatullab observes also that it is unclear whether the doctrine referred to by the Supreme Court is that of foreign of Crown act of state [2015] EWCA Civ 843, [320]. The better reading is that it is the latter.

67 [2015] EWCA Civ 843, [323]. 
act of state. The point can be made with reference to the two categories of nonjusticiability identified by the Supreme Court in Shergill $v$ Khaira and reiterated by the Court of Appeal here. The first such category includes circumstances in which the issue in question is beyond the constitutional competence assigned to the courts under our conception of the separation of powers', such as in relation to the transactions of foreign states and proceedings in Parliament. ${ }^{68}$ In this category, 'once the forbidden area is identified, the court may not adjudicate on the matters within it, even if it is necessary to do so in order to decide some other issue which is itself unquestionably justiciable'. ${ }^{69} \mathrm{By}$ contrast, in the second category, 'comprising claims or defences which are based neither on private legal rights or obligations, nor on reviewable matters of public law', this inability to look past the non-justiciability of the matter does not apply. Instead, the courts will adjudicate upon the matter if 'a justiciable legitimate expectation or a Convention right depends on it' as it will also in the case of private law liabilities. ${ }^{70} \mathrm{~A}$ key example, the Supreme Court said in Shergill, is that in which 'the court declines to adjudicate on the international acts of foreign state or to review the exercise of the Crown's prerogative in the conduct of foreign affairs' ${ }^{71}$

Though the Supreme Court in Shergill had, as noted above, implicitly distinguished the Crown act of state doctrine from non-justiciability proper, it would seem to logically follow that one or other of these positions must be the case for that doctrine to the extent it is based upon a non-justiciability rule. The references by the Supreme Court, in relation to that second category, to the prerogative, the rule against the reviewability of which has often been identified (as by Leggatt J in Serdar Mohammmed) with the non-justiciability limb of Crown act of state, give some weak basis for thinking that the Crown act of state nonjusticiability rule works as does the second category of general non-justiciability identified in Shergill. Nevertheless, the better view must (unfortunately) be that the non-justiciability element of Crown act of state, where it operates, does so in the same manner as in the first category of non-justiciability in Shergill. Most clear, and probably dispositive of the question, is that where it comes to discuss the compatibility of the act of state doctrine with Article 6 of the Convention on Human Rights, the Court of Appeal makes specific reference to the first category of non-justiciability, noting that it is 'not concerned in this case with the second category of non-justiciability identified by the Supreme Court . . . as the claimants seek to invoke private law rights'. ${ }^{72}$ This conclusion is buttressed by the Supreme Court's references in Shergill to transactions of foreign states (the original subject of the act of state doctrine) and to the separation of powers, which Leggatt $J$ had identified as the basis of the non-justiciability rule in Serdar Mohammed. ${ }^{73}$ Finally, this conclusion would seem to follow from a consideration of the basic logic of the situation: if the non-justiciability rule is equivalent to the Supreme Court's second category of nonjusticiability in Shergill, then that limb of Crown act of state has been hollowed out even further than Leggatt J suggested has been the case, to the point that it is not clear that it could ever actually prevent the courts from hearing a case, no matter how grand the questions of foreign (or other) policy upon which it would require the court to adjudicate. The effect of assimilating the non-justiciability rule of Crown act of state to this first category of general non-justiciability is that the court cannot enter a 'forbidden area' even

68 Shergill v Khaira [2014] UKSC 33, [42].

69 Ibid [42].

70 Ibid [43].

71 Ibid.

72 [2015] EWCA Civ 843, [371].

73 [2014] EWHC 1369 (QB), [373]. 
if to do so is necessary in order to decide private law rights, a conclusion which gives further reason for believing that the act giving rise to the tort should be framed as narrowly as is plausible, so as to keep it - if at all possible - outside the realm of nonjusticiability. When the matter is considered by the Supreme Court it would do well to consider splitting the difference, by distinguishing the different factors identified by the Court of Appeal as rendering a matter non-justiciable - briefly, the need to consider questions of high policy, the absence of judicial standards and questions of constitutional appropriateness - and assimilating only the third of these to the first category of nonjusticiability identified in Shergill. In relation to the first factor in particular, there is no reason to believe that it alone justifies the courts refusing to consider a matter where it is necessary for them to do so in order to determine an individual's legal rights. It should be, therefore, brought within the second category of Shergill non-justiciability. If this sort of differentiation in turn encourages the courts to clarify what are the various bases of non-justiciability and the manner in which they interact, then so much the better.

This apparent shift in the explanation of the non-justiciability limb of Crown act of state raises further questions about Crown act of state, justiciability and the prerogative. First, does the shift indicate that the non-justiciability limb of the Crown act of state doctrine is not limited to circumstances in which the act giving rise to the tort claim is carried out under the prerogative powers (and has therefore been increased in scope)? This point is subtle. The reason why the two matters have often been conflated is that, to the extent that non-justiciability arises in the context of foreign affairs, it applies to powers which in the modern constitution are found entirely within the prerogative. Nevertheless, the approach which the courts have taken to reviewability in the prerogative case law is, as discussed, now unambiguous: reviewability is a function of the subject matter of a power rather than its legal source. There is, therefore, it seems, no longer any basis for distinguishing between the question of justiciability as regards the prerogative and as regards other sources of legal authority. In turn, this suggests that, though the Crown act of state non-justiciability rule has often been thought of as an instantiation of the prerogative's non-reviewability, it might apply equally beyond the prerogative. In fact, the best understanding may be that the prerogative was never truly non-justiciable per se, but instead that the subject matter of all or most of the prerogative powers was nonjusticiable, rendering the prerogative non-justiciable only indirectly and contingently what has changed over time has not been the courts' approach to the review of the prerogative, but the range of subject matters of which they regard themselves as unable to take cognisance. If the significance of this reconceptualisation by the Court of Appeal is only potential rather than actual, it is because there are no powers to conduct foreign affairs which exist in statute rather than the prerogative - nothing, that is, on which the now rethought (and so implicitly widened) rule can be brought to bear. Following from this, a second question: if this limb of the doctrine is nothing more than an instantiation of the general approach taken by the courts to the question of justiciability, what reason is there for separating it out and packaging it as an aspect of a separate doctrine? The answer seems to be that there is none. To the extent that it is a rule of justiciability, the doctrine of Crown act of state adds nothing to, but in fact merely reflects, general principles of (non-)justiciability and the understanding of the appropriate constitutional separation of power which underpins them. These principles may 'bite' more frequently on 'acts of state' as Wade understood them, but they will not do so inevitably or exclusively and any such act will include under its umbrella an infinite number of lesser acts which are unambiguously justiciable. The Court of Appeal has therefore reaffirmed here the doctrine's dualism by confirming the existence of the doctrine's tort defence 
limb, only to simultaneously offer an understanding of the non-justiciability limb which calls that dualism back into question by showing that this first limb is not a rule of law special to the Crown.

To return to the cases at hand, the detention of Serdar Mohammed was accepted by the Court of Appeal, as it had been by the High Court, to be suitably distant from any decision of high policy as to be well within the scope of the courts' jurisdiction, similar issues having been already considered in the context of judicial review claims. ${ }^{74}$ Because the adjudication of Serdar Mohammed's claims could take place without entry into any 'forbidden area', the non-justiciability rule was no bar to it. But despite it having accepted Leggatt J's hollowing-out of the non-justiciability rule, the Court of Appeal noted the possibility that, contrary to what had been said at first instance, the claims of Rahmatullah ${ }^{75}$ might be caught even by the now-eroded rule. To explain why requires an understanding of Al-jedda $v$ Secretary of State for Defence, ${ }^{76}$ a previous case arising out of the military action in Iraq and Afghanistan in which Crown act of state was pleaded. The claimant had been arrested in Iraq in 2004 and detained by UK forces in a military detention centre. After his release, he sought damages for unlawful imprisonment. When Al-Jedda's tort claim arrived in the Court of Appeal, the majority took the view that his detention was lawful under Iraqi law and so his appeal, from the decision of Underhill J, was dismissed without any binding decision about Crown act of state having been made. Nevertheless, two of the members of the Court of Appeal - Arden LJ, who dissented on the lawfulness of the detention under Iraqi law and whose views on Crown act of state were therefore dispositive of the issue for her, and Elias LJ - expressed the view that, as had been suggested by the judge at first instance, the doctrine of act of state in its nonjusticiability form was applicable here, preventing the courts from enquiring into the legality of the detention. This view was, however, a function of the earlier House of Lords decision in Al-Jedda (No 1$)^{77}$ that detention for the purpose of the internal security of Iraq was rendered obligatory by UN Security Council Resolutions which, though couched in the language of authorisation and not obligation, bound the UK to detain individuals where it was necessary for the internal security of Iraq. It was this obligation which transformed the specific act of detention from a probably justiciable decision into one over which the doctrine of Crown act of state would have displaced the courts' jurisdiction. ${ }^{78}$ It is this same logic - not strictly part of the ratio of Al-Jedda (No 2) - which the Court of Appeal in Serdar Mohammed/Rahmatullah suggested might have been capable of distinguishing Rahmatullah's detention from that of Serdar Mohammed, such that the non-justiciability rule would exclude the consideration of the former and not the latter.

Viewed in light of later decisions, this account of the application of Crown act of state to the facts of Al-Jedda is problematic. Why does the erosion of the general rules of non-justiciability which was accepted in Serdar Mohammed both at first instance and on appeal not similarly place the specific decision to detain Al-Jedda firmly back within the courts' purview, given the distance between the decision to take military action and the decision to detain the particular individual? As noted by Leggatt J in Rahmatullah, '[i]t was not necessary to challenge the decision to send British forces to Iraq in order to judge

$74 \mathrm{R}$ (Maya Evans) v Secretary of State for Defence [2010] EWHC 1445 (Admin).

75 Along with the so-called 'Iraqi civilian claimants'.

76 Al-jedda v Secretary of State for Defence (No 2) [2010] EWCA Civ 758.

77 [2007] UKHL 58.

78 [2010] EWCA Civ 758, [108]-[110] and [195]. 
whether the detention of $\mathrm{Mr}$ Al-Jedda was lawful under Iraqi law'. ${ }^{79}$ But even if the principle of the issue were - contrary to the view taken by Leggatt J in Serdar Mohammed and in Rabmatullab and endorsed on appeal ${ }^{80}$ - unimpeachable, the conclusion is built upon a shaky foundation. The House of Lords' decision in Al-jedda (No 1) that the claimant's detention was not merely authorised but required by the UN Security Council resolutions, and his rights under Article 5 of the European Convention on Human Rights (ECHR) were therefore ousted (by virtue of the UN Charter's subordination of all other international legal obligations to the writ of the UN), ${ }^{81}$ was called into question by the decision of the European Court of Human Rights in Strasbourg. It was there held that, contrary to the House of Lords' assessment, 'neither Resolution 1546 nor any other United Nations Security Council Resolution explicitly or implicitly required the UK to place an individual whom its authorities considered to constitute a risk to the security of Iraq into indefinite detention without charge'. ${ }^{82}$ If accepted by the domestic courts, this assessment would break the link, upon which the relevant remarks in the Court of Appeal's decision in Al-jedda (No 2) are predicated, between the indisputably nonjusticiable choice to contribute British forces to the Multi-National Force in Iraq and the specific act of detaining Al-Jedda. Though it is the House of Lords' decision which continues to bind the domestic courts, the Supreme Court has given permission to appeal to a case (in respect of which Leggatt J granted a leapfrog certificate) ${ }^{83}$ which challenges the decision of the House of Lords on the UN point. If that claim succeeds, the defence of act of state as the majority of the Court of Appeal in Al-Jedda (No 2) would have applied it will be unavailable in relation to the detention of individuals in Iraq, the decision to detain not being attributable to an overriding obligation arising from the UN Charter. Leggatt J therefore suggested in Rabmatullah that, insofar as it is necessary to explain it, Al-Jedda should be explained (contrary to the terms in which it was in fact decided) 'on the basis of the narrower Crown act of state defence rather than by invoking the rule of justiciability' ${ }^{84}$ This conclusion was endorsed by the Court of Appeal in the joined cases: the 'observations in Al-Jedda on the applicability of the act of state principle cannot be justified on grounds of non-justiciability'. ${ }^{85}$ As such, the possible distinction floated between the situations in Afghanistan and Iraq was illusory and the (eroded) nonjusticiability rule failed also to exclude the consideration of Rahmatullah's claim.

To conclude on the non-justiciability rule: the overall effect of this element of the recent series of decisions will be to deprive the rule of much of its practical effect. That is, though it is accepted that matters of high policy remain non-justiciable, it will not always, or even usually, be the case that, where a tort claim is advanced, the specific action or decision allegedly giving rise to it will exist in a sufficiently close nexus with such matters as to be similarly excluded. Indeed, such a situation may, in fact, be highly exceptional. Instead, a litigant will be challenging the specific action which affects him or her as an individual, which the courts will usually and rightly characterise as a separate act, capable of being adjudicated upon by the courts without them carrying out any

79 Yunus Rabmatullah v Ministry of Defence [2014] EWHC 3846 (QB), [194].

80 [2015] EWCA Civ 843, [323].

81 United Nations Charter, Article 103: 'In the event of a conflict between the obligations of the Members of the United Nations under the present Charter and their obligations under any other international agreement, their obligations under the present Charter shall prevail.'

82 Al-Jedda v UK (2011) 53 EHRR 23.

83 Al-Wabeed $v$ Ministry of Defence [2014] EWHC 2714 (QB).

84 [2014] EWHC 3846 (QB), [197].

85 [2015] EWCA Civ 843, [330]. 
illegitimate foray into the conduct of foreign policy, which, they recognise, remains the exclusive province of the executive. ${ }^{86}$ Though there undoubtedly exists, at least in theory, a category of actions or decisions which are capable of giving rise to a claim in tort but which are in fact themselves by nature non-justiciable, that category is likely to be small, and the smaller it is, the less significant is the non-justiciability rule of Crown act of state. More fundamentally, however, the treatment of the issue in the Court of Appeal suggests that it is no longer sensible to consider the non-justiciability rule as an aspect of some special doctrine of Crown act of state and so to focus attention on what is or is not such an act. It is an instantiation of general principles of justiciability which are not unique in their application to the Crown, to the prerogative, or even to those acts traditionally designated 'acts of state'. To conceive it as such makes room for a more determined focus upon those general principles.

\section{The tort defence}

The cumulative effect of the cases which are the subject of this article has been to erode the tort defence rule of Crown act of state to at least the same extent as the nonjusticiability rule. The basis of that erosion is, however, more direct and deliberate, being the conscious effect of those cases rather than - as was mostly the case with the nonjusticiability rule - merely the effect of bringing to bear upon it several decades of evolution elsewhere in the constitutional order. As noted, the separate existence of this second rule was confirmed, in the face of direct challenge to it, by both the High Court and Court of Appeal. Yet that rule, though so closely tied to the non-justiciability rule as to subsist within the same doctrine, must - if it is not to be considered to have been undermined in the same way, and for the same reasons, as has been that first rule - not only be something other than a mere instantiation of the non-justiciability rule, but have a separate basis from it altogether; one which survives the constitutional developments of GCHQ and Bancoult and so on. The basis identified by Leggatt J in Serdar Mohammed was that, in the field of foreign relations, court and executive should speak with 'one voice'87 - though in relation to the rights and liberties of the subject at home, the courts may and indeed must protect the individual against the executive, very different considerations apply in the field of foreign affairs, such that the individual has no expectation to be protected against unlawful executive action. ${ }^{88}$ This would not prevent the courts applying domestic public law principles to actions taken by agents of the UK in Afghanistan, but, he said, '[i]t is not the business of the English court to enforce against the UK state rights arising under Afghan law for acts done on the authority of the UK government abroad, where to do so would undercut the policy of the executive arm of the UK state in conducting foreign military operations' ${ }^{89}$ The Crown act of state doctrine is on this view (re-)conceptualised as an exception to the general principle permitting foreign torts to be the basis of a claim in domestic courts where the foreign law is the applicable law, analogous to the rule whereby English courts will refuse to enforce a right arising under

86 This was essentially the basis upon which Nissan was resolved, with four of the five judges in the House of Lords taking the view that there was not a sufficiently close connection between the conclusion of the international agreement and the occupation of the hotel for the latter to fall within the doctrine. Lord Reid similarly held that a claim of act of state was not possible, though on the basis that the plaintiff was a British subject.

87 Three cases are cited in which reference was made to the one-voice principle: Al-Jedda v Secretary of State for Defence [2009] EWHC 397 (QB), [212]; Government of the Republic of Spain v SS 'Arantzazu Mendi' [1939] AC 256, 264; British Airways Board v Laker Airways Ltd [1984] 1 QB 142, 193.

88 [2014] EWHC 1369 (QB), [394].

89 Ibid [395]. 
foreign law if to do so is contrary to public policy: 'its effect is to preclude the enforcement of that tort claim in the courts of this country'. ${ }^{90}$ Leggatt J was at pains to emphasise how narrow is the rule on the basis of which the tort claim here fails: it applies 'only to executive acts done abroad pursuant to deliberate UK foreign policy'; those 'which are directly authorised or ratified by the UK government'. ${ }^{91}$ But the decision to detain Serdar Mohammed was such an act: the defence of act of state succeeded there, ${ }^{92}$ as it would have also on the approach of the High Court in Rabmatullah, if it could be shown that his arrest and detention was in accordance with the UK's detention policy. ${ }^{93}$

Because it may yet prove relevant, several points can be made as regards this conceptualisation of the public policy underlying the choice of laws rule. The first is that it demonstrates what we may have already suspected: there is no coherence whatsoever to the doctrine of Crown act of state, the two rules of which are wholly separate from each other and contingently combined under an umbrella term which can now be seen to be deeply misleading. The second is that it is poorly grounded in the case law - in evidencing it Leggatt J relied not on anything said in the various Crown act of state cases but instead on the characterisation of Buron $v$ Denman found in a textbook on the conflict of laws, providing an account of the rule which does not unambiguously follow from the terms of the case. ${ }^{94} \mathrm{~A}$ third point: the cases cited in relation to the one-voice principle speak primarily to a different set of circumstances - that where the executive has an official opinion on a question which must be taken to be an opinion of the state as a whole and with which it makes no sense for the courts to disagree. The paradigmatic example is the question of whether a certain state exists, as was at issue in Government of the Republic of Spain v SS 'Arantrazu Mendi'. ${ }^{95}$ Here, instead, insofar as there is a relevant question on which the executive and the courts might disagree, it is a question of law, and who but the courts are entitled to form an authoritative view on such a question? To take such a view and then discard it as a matter of policy is an unfortunate extension of the one-voice principle which provides an unattractive incentive for the executive to act in a way that it knows - as it did here - to be unlawful. Fourth, the conceptualisation of the act of state offered here would seem to be in tension with the claim made by Leggatt $\mathrm{J}$ in Rahmatullah that, despite what was argued there, not only does the defence exist, but that it 'rests on a proper appreciation of the separation of powers'. 96 If courts choose, even in a limited field, to speak as they are mandated to do by the executive, then what is taking place is not an actualisation of the separation of powers ideal but its denial. Fifth, and finally, the explanation of the tort defence offered by Leggatt $J$ at first instance is not just a merely technical clarification of the rule's basis. Had it been accepted by the Court of Appeal, it would have widened the scope of the overall doctrine of Crown act of state. We can make the point by considering the invocation of Crown act of state in Nissan v Attorney General, which failed because the taking of the hotel was not sufficiently closely connected to an 'act of state' (the making of an agreement with Cyprus) for it to fall within the non-

90 [2014] EWHC 1369 (QB), [396].

91 Ibid [397].

92 Ibid [395].

93 [2014] EWHC 3846 (QB), [224].

94 [2014] EWHC 1369 (QB), [391], quoting Dicey, Morris \& Collins, The Conflict of Laws 15th edn: Lord Collins et al. (eds) (Sweet \& Maxwell 2015) [5-057]: 'X, an officer of the Crown, duly authorised, destroys property of A, a Spanish subject at a place outside the United Kingdom and Colonies. Spain and the United Kingdom are at peace, and X's act is tortious by the law of the place where it is committed. X's act is an act of state, and the court will not entertain an action by A against X.'

95 [1939] AC 256.

96 [2014] EWHC 3846 (QB), [208]. 
justiciability rule. However, applied to those same facts, the tort defence would, on the approach of Leggatt $J$ here, have succeeded: the taking of the hotel may not have been an act of state or suitably closely connected to one, but was presumably nevertheless within the category of 'executive acts done abroad pursuant to deliberate UK foreign policy'. ${ }^{97}$ What this suggests is that, though the combined decisions of Leggatt J in Serdar Mobammed and Rabmatullab weakened the non-justiciability rule (having the desirable effect of asserting the courts' jurisdiction over acts which would previously have escaped it), the range of actions in respect of which tort claims would be barred by Crown act of state was in fact widened by them. This must be counted as both perverse and retrogressive.

These points are, however, of less significance than they might have been as a result of the decision of the Court of Appeal that, though this limb of the act of state doctrine is indeed a procedural rule of domestic law reflecting public policy, the public policy considerations must be assessed on a case-by-case basis and, as such, the tort defence will not succeed simply because the conduct giving rise to the claim is 'a sovereign act done abroad pursuant to deliberate foreign policy'. ${ }^{98}$ This conclusion is justified in part on the basis that there does not exist a similar bar in relation to public law claims (and nor is the defence available in relation to claims under the HRA), and in part on the sense that the tort defence as conceptualised by Leggatt J was simply out of place - 'no longer sustainable' - in the modern constitutional context. ${ }^{99}$ Drawing an intriguing comparison between the tort defence of the Crown act of state doctrine and the law on public interest immunity before and after Conway $v$ Rimmer, ${ }^{100}$ the Court of Appeal held that, in deciding whether the defence should be available, the courts should consider 'whether, in the particular factual circumstances of the case, there are any compelling considerations of public policy which would require the court to deny a claim in tort founded on an act of the Executive performed abroad'. ${ }^{101}$ We can, it seems, understand from this that the default situation will be that the tort defence does not apply even to acts done pursuant to a deliberate foreign policy - only where sufficient justification is given to depart from that default will the executive convince the courts to bar the tort claim in question. Moreover, it seems that even any compelling considerations identified in favour of barring a tort claim would require to be balanced against countervailing considerations in favour of rejecting the defence: it was accepted by the Secretary of State that claims for torture could not be repelled on this basis, ${ }^{102}$ while the Court of Appeal took the view that the tort defence, as a reflection of public policy, is unlikely to be capable of successful invocation if the conduct in issue constituted a grave breach of international law or human rights law'. ${ }^{103}$ Having rejected the specific public policy rationale identified by Leggatt J, the Court of Appeal has deprived the executive of the ability to bar certain claims on the basis of little more than its mere say-so. As a correlate, it has acquired for the courts a new decision-making authority, according to which it will determine whether or not the reasons offered for seeking to bar certain tort claims are suitably compelling. The decision of the Court of Appeal therefore neatly fits the pattern of administrative law in the last half-century or so, whereby the courts have slowly but surely rewritten

97 Leaving aside the question of whether the fact that the claimant was British would, as Lord Reid suggested, have prevented the pleading of Crown act of state.

98 [2015] EWCA Civ 843, [352].

99 Ibid [358].

100 [1968] AC 910, [1968] 2 WLR 998.

101 [2015] EWCA Civ 843, [359].

102 Ibid [357].

103 Ibid [374]-[375]. 
notions of constitutional appropriateness, dismantled distinctions which exempted certain executive acts from judicial oversight, and intensified standards of review so as to obtain greater scope to subject to scrutiny the actions of the executive even in its most precious policy areas and to require, as a condition of any attempt to avoid that scrutiny, that the executive justify itself to the courts.

More than that, however, in thus narrowing the tort defence the Court of Appeal has given reason to doubt the usefulness of conceptualising the rule as the aspect of an overarching doctrine known as Crown act of state. That is, unlike in the case of the doctrine as understood by Leggatt J, which stays largely true to the past understanding of the rule's effect (if not its nature), the Court of Appeal has held that just because an act was done by the Crown in pursuit of its foreign policy does not mean a claim arising out of it will be barred. Not only is this not a sufficient condition, however: neither is it a necessary one. The same public policy considerations which may bar a claim based on foreign law in relation to an 'act of state' may similarly bar a claim which does not involve any such thing: the rule, we now see, is merely a general rule of public policy which is a well-known feature of the choice of laws and which is acknowledged within the 1995 Act by a saving provision which provides that nothing in the relevant part 'authorises the application of the law of a country outside the forum as the applicable law for determining issues arising in any claim in so far as to do so . . . would conflict with principles of public policy'. ${ }^{104}$ At first instance, Leggatt $\mathrm{J}$ had suggested that his own understanding of the tort defence was analogous with this rule. The better view, the decision of the Court of Appeal shows, is that it is simply a manifestation of it, one which does not apply uniquely, or even specially, to the Crown: it would bar a claim of the sort at issue in Buron $v$ Denman, but would (in present circumstances) do so even if the defendant was a private party rather than the Crown, given that the enforcement of property rights in slaves would undoubtedly be contrary to public policy. Though the public policy considerations which apply to alleged acts of state may be different, or apply with different weight, the balancing act the courts must undertake is a familiar one, not unique to such acts. In clarifying and narrowing the rule, these judgments have therefore clearly demonstrated that it no longer, if it ever did, makes sense to think of a distinct doctrine of Crown act of state - better to think of two rules, one of justiciability, one of the choice of laws, which will apply (but not exclusively) to certain acts of the Crown, either preventing the courts from adjudicating upon those acts, or barring tort claims arising out of them. To continue to treat the doctrine as something distinct and special as reflecting a privileged legal status of either the Crown or certain of its acts - would be to wrongly reify it and would obstruct a clear view of what should and will be the legal consequences of the acts of the Crown abroad.

Where at first instance the tort defence had been held to bar the claims of both Serdar Mohammed and Rahmatullah, the tighter understanding of public policy - to be considered on a case-by-case rather than blanket basis - endorsed by the Court of Appeal leads to very different results. In the case of Mohammed, having emphasised the Secretary of State's decision to authorise a detention policy 'outside and contrary to the authority' granted by the UN Security Council Resolutions and contrary to Afghan law, as well as his failure to put proposals for legislation barring tort claims of this sort (as had been done in the USA), the court held that it could see no "compelling considerations of public policy which should prevent reliance on Afghan law as the basis of the claims in 
tort brought in these proceedings'. ${ }^{105}$ That is, where Leggatt J's understanding of public policy caused Mohammed's claim to be barred, the new, stricter approach of the Court of Appeal means that it can proceed. For Rahmatullah and the Iraqi civilian claimants, the result was ambiguous (though still more favourable to the claimants than that of the High Court) in that the question of where the balance of public policy considerations lay was left open for determination at trial. It is clear, however, that a key factor in that decision will be whether or not the UK was under an overriding obligation, arising out of Security Council resolutions, to detain or intern 'for reasons of security' in Iraq. ${ }^{106}$ As discussed above in the context of the Al-Jedda case, that question will soon be revisited by the Supreme Court. If it follows the Strasbourg Court in holding that, contrary to its own decision in Al-jedda (No 1), the UK was under no such obligation, it seems likely that the Crown act of state defence will ultimately fail in barring the tort claims of Rahmatullah and the Iraqi civilians. The Al-Jedda (No 1) issue may, however, ultimately impede Rahmatullah's tort claim via the tort defence notwithstanding that the severability of the high policy decision to go to war from the specific decision to detain meant that it failed to do so under the non-justiciability rule.

Two further issues regarding the tort defence were raised for the first time before the High Court in Rabmatullah and dealt with there and on appeal. The first was the claim that, even if the defence of Crown act of state had previously existed, it was abolished by the Crown Proceedings Act 1947, s 2(1) of which renders the Crown subject to the normal liabilities in tort in respect of torts committed by its 'servants or its agents', on the proviso that 'no proceedings shall lie against the Crown ... in respect of any act or omission of a servant or agent of the Crown unless the act or omission would apart from the provisions of this Act have given rise to a cause of action in tort against the servant or agent or his estate'. It was noted above that the origins of the doctrine of Crown act of state date to an era, put to an end by the 1947 Act, in which the Crown could do no wrong; a rule which entailed, for present purposes, that it could not be liable in tort. The argument advanced here was that the defence of Crown act of state was an aspect of the Crown's general immunity in tort and so it, like that more general immunity, was extinguished by the statutory intervention. Leggatt $J$ at first instance rejected this claim; ${ }^{107}$ that the Court of Appeal endorsed his rejection of it is, of course, of less significance given that it did so in the context of a diminished, rather than enhanced, tort defence. ${ }^{108}$ More important is the claim that the defence of Crown act of state is a procedural bar which interferes with a claimant's rights under Article 6 of the ECHR one which, even if it pursues a legitimate aim, does so in an arbitrary and disproportionate way. Leggatt $J$ rested his conclusion as to the proportionality of the procedural bar - and therefore its compliance with Article 6 - on the limited scope of the doctrine, which applies only to acts 'done abroad pursuant to deliberate UK foreign policy', and only to claims arising under foreign law (and so not to HRA claims). ${ }^{109}$ Nothing in the doctrine prevents any claim being brought in any other jurisdiction, while it remains open to the claimant to challenge the legality of the policy in pursuit of which the acts were committed on English public law grounds. ${ }^{110}$ The doctrine's alleged disproportionality was attributed in large part to its potential retrospective operation - i.e.

105 [2015] EWCA Civ 843, [359].

106 Ibid [368].

107 [2014] EWHC 3846 (QB), [212]-[215].

108 [2015] EWCA Civ 843, [345].

109 [2014] EWHC 3846 (QB), [218].

110 Ibid [218]. 
that it can operate as a defence to tort claims arising out of actions which were 'adopted' subsequent to taking place rather than being authorised in advance, as had happened in Buron $v$ Denman. This point was left open, however: the actions out of which Rahmatullah's tort claims emerge were carried out pursuant to a policy established in advance and so there was no need to confirm whether retrospectivity renders the procedural bar a disproportionate interference with a claimant's Article 6 rights. ${ }^{111}$ The Court of Appeal, by contrast, treated the two limbs of the doctrine separately. Though its conclusions as to the applicability of the non-justiciability rule rendered the question of the rule's compatibility with Article 6 academic, the court indicated its belief in that compatibility, given that the non-justiciability rule, in reflecting limitations on the role of the judicial function which are inherent in the allocation of powers under our constitution', clearly pursues a legitimate aim in a proportionate manner. ${ }^{112}$ In arriving at the same conclusion as to the compatibility of the tort defence with Article 6 as had Leggatt J, however, the Court of Appeal suggested that the tort defence as conceptualised at first instance would not be compatible: the absolute nature of the bar would - even if the one-voice principle were recognised as a legitimate aim - be neither a necessary nor a proportionate means of achieving it in light of the unfettered ability to bring public law and human rights claims arising out of the same facts. ${ }^{113}$ The tort defence was compatible with Article 6 only because it was rewritten by the Court of Appeal to reflect a fact-specific, case-by-case consideration of public policy.

Finally, alongside the clear and significant narrowing of both the non-justiciability rule and the tort defence, one further issue must be mentioned briefly - the clarification that neither of the doctrine's two rules bars claims under the HRA. This conclusion was arrived at by Leggatt $J$ on the straightforward basis that act of state is a feature of the common law which 'has been overridden by Parliament when it enacted the Human Rights Act'. 114 To read into that Act an implied exception to the basic s 6(1) rule in relation to acts of state would be incompatible with its purpose and create an unwelcome divergence between the enforcement of the ECHR in domestic law and before the Strasbourg Court, to which the doctrine is of no relevance. ${ }^{115}$ The Court of Appeal concurred: ${ }^{116}$ the narrowing of the doctrine within its traditional domain(s) was therefore accompanied by a refusal to permit its expansion into other areas of law.

\section{Conclusion}

The doctrine of Crown act of state is much diminished. It is now clear that the nonjusticiability element does not apply to HRA claims, while the tort defence rule permits both those and public law claims. Even where each of the doctrine's rules does apply, their scope is far more limited than would have been understood until recently. All of this is welcome - the very existence of the doctrine is in tension with the rule of law and its progressive limitation is a victory for that idea even if (as seems possible) it ultimately encourages Parliament to legislate in order to fill the gap which recent decisions have opened up. More than that, however, the rethinking of these rules, which has been precipitated by military endeavours in Iraq and Afghanistan, calls into question the coherence of the doctrine qua doctrine. First, because the two rules comprising the

111 [2014] EWHC 3846 (QB), [220]-[221].

112 [2015] EWCA Civ 843, [371].

113 Ibid [372]. I take the necessity point to be the implication of the final sentence of that paragraph.

114 Serdar Mohammed v Ministry of Defence [2014] EWHC 1369 (QB), [412].

115 Ibid [413].

116 [2015] EWCA Civ 843, [354]. 
doctrine are so different in their basis and their application as to be essentially unrelated. Second, and more fundamentally, because it is now clear that neither rule is unique in its application to the Crown or even to those acts traditionally identified as 'acts of state'. The older rule is an instantiation in the field of foreign affairs of general principles of justiciability and non-justiciability which themselves reflect the undeniable fact that some questions (which, we may debate) are unsuitable for judicial determination. The second is a rule of the conflict of laws reflecting general considerations of public policy which require a case-by-case examination of the relevant act within its specific legal and factual context. The doctrine has been exposed to the scrutiny of courts, which have long since ceased to automatically defer to the executive in the field of foreign affairs, and it has been found wanting. It should now be abandoned, so as to allow the difficult questions of the separation of powers and public policy which lurk behind the two rules to take centre stage. 